\title{
Long-Term Impact of Balanced and Imbalanced Fertilization in Rice under Rice-Wheat Sequence in Mollisols on Relationship between Microbial Activity and Yield
}

\author{
Mohd. Yaseen ${ }^{1 *}$, K.P. Raverkar ${ }^{1}$, Ramesh Chandra ${ }^{1}$, Navneet Pareek ${ }^{1}$, \\ Subhash Chandra ${ }^{2}$ and D.K. Singh ${ }^{2}$ \\ ${ }^{1}$ Department of Soil Science, ${ }^{2}$ Department of Agronomy, College of Agriculture, G.B. Pant \\ University of Agriculture and Technology, Pantnagar 263 145, India \\ *Corresponding author
}

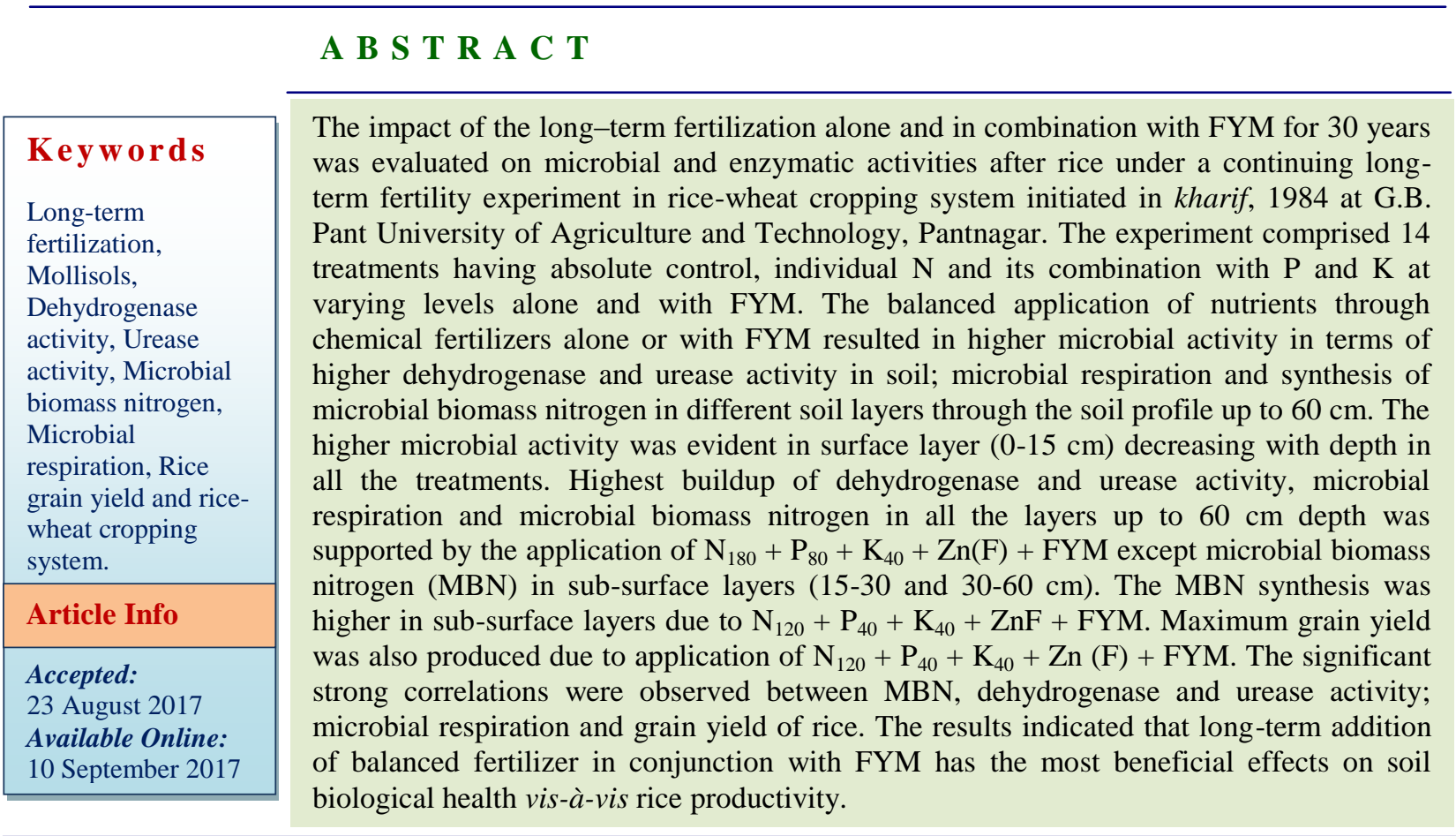

\section{Introduction}

Soil management practices such as tillage, crop rotation, green manuring, and nutrient management practices influence the soil's capability to support the productivity of the crops. In general these practices directly or indirectly affect the biological soil health vis$\grave{a}$-vis nutrient supply to the crops. Soil microorganisms are essential for the longterm sustainability of agricultural systems (Wardle et al., 1999) as they mediate the biological processes influencing the organic matter decomposition, humus formation, and nutrient cycling through enzymatic activities (Smith and Paul, 1990; Sinsabaugh et al., 
1991). Soil enzymes are pivotal components involved in the dynamics of soil nutrient transformations (Masto et al., 2006). Enzyme activity in the soil environment is considered to be the major contributor of overall soil microbial activity and soil quality (Roldan et al., 2005). Soil enzymes occur as exo- and endoenzymes present in viable microbial cells and are a part of the soil matrix (Dick et al., 1994). Soil enzyme activities are commonly correlated with microbial parameters thus can be a sensitive index to evaluate the long-term management effects of organic and green manures; tillage (Deng and Tabatabai, 1997; Dick et al., 1988; Kirchner et al., 1993) and chemical fertilizers.

Biological soil quality can also be judged by measuring the soil microbial biomass and microbial activity as have been considered as important indices (Schloter et al., 2003). The soil biological parameters respond quickly in a year or two to crop and soil management practices (Livia et al., 2005). The application of nutrients inadequately and/ or imbalanced use of fertilizer with meager or no use of organic manures deteriorates the productivity of soil leading to the poor soil quality because of low biomass production.

In developing world the nutrients are not provided adequately for the crop production being costlier and poor purchasing power of farmers leading to deterioration of soil quality and unsustainability of soils. Rice-wheat is a dominant cropping system and it occupies $13.5 \mathrm{~m}$ ha in the Indo-Gangetic Plains of Bangladesh, India, Nepal, Pakistan (Ladha et al., 2000). Long-term fertilizer experiments are vital tools to assess management induced variability on sustainability and processes occurring in soil during nutrients turnover. Long-term application of chemical and organic amendments significantly influences the quality and productivity of soil, mainly through improving nutrient availability to plants and microorganisms (Acton and Gregorich., 1995). Both chemical and organic amendments can maintain or improve crop yields, and their application can directly or indirectly causes changes in soil chemical, physical and biological processes vis-à-vis properties (Belay et al., 2002). Microbial respiration can also be employed as an index of biological activity of soil as it depicts the physiological efficiency of soil microbes.

Therefore, the present investigation was carried out with the hypothesis that balanced and imbalanced fertilization with or without FYM in rice-wheat system in Mollisols for a long-term will have differential impact on enzymatic activities, microbial activity and their relation to yield of rice. The outcome of the study will be helpful to pinpoint the nutrient management practice(s) for rice sustainability under rice-wheat system in Indo-Gangetic Plains (IGP) to keep the soil sustainable and healthy.

\section{Materials and Methods}

\section{Experimental site and soil characteristics}

The long-term experiment is continuing in $\mathrm{A}_{2}$ block of Norman E. Borlaug Crop Research Centre of G.B. Pant University of Agriculture and Technology, Pantnagar, (Uttarakhand), which lies in a narrow belt under the foothills of the Shivalik range of Himalayas since 1984. The experimental site falls in the subhumid, sub-tropical climate zones locally known as the Tarai region, situated at $29^{\circ} \mathrm{N}$ latitude and $79^{\circ} 3$ 'E longitude and at an altitude of 243.84 metres above mean sea level in Uttarakhand. The Tarai area has a dry season from early October to mid-June, and a wet season from mid-June to early October. Temperatures are highest in MayJune and lowest in December-January. Relative humidity is highest in July-August and lowest in April-May. Total rainfall 
ranges from 1300-1500 $\mathrm{mm}$ per annum of which about $85-90 \%$ is received from June to September.

The soil of the experimental plot is alluvial in origin, silty loam in texture, relatively young and is classified as Aquic Hapludoll. The initial soil properties recorded in 1984 for 0$15 \mathrm{~cm}$ depth are given in table 1 .

\section{Experimental design and treatments}

The experiment has been laid in Randomized Block Design (RBD) with fourteen treatments and four replications (Tables 2 and 3). During kharif and rabi seasons, rice (cv. Pant Dhan 4) and wheat (cv. UP 2425) were taken as test crops at a fixed site with the same layout plan.

\section{Soil Sampling and biological parameters}

After completion of the $30^{\text {th }}$ cycle of rice in 2014-15, representative soil samples from 0$15,15-30$ and 30-60 $\mathrm{cm}$ depth were collected. The samples were stored at 0-40 $\mathrm{C}$ for the assessment of biological properties and were exposed within 20-30 days of sampling.

Dehydrogenase activity was measured by the method listed by Casida et al., (1964) and urease activity employing the method of Pal et al., (1981). The microbial respiration was recordded by the alkali trap method (Anderson, 1982). Microbial biomass nitrogen in soil samples was estimated by chloroform fumigation and extraction method as described by Brookes et al., (1985) and modified by Vance et al., (1987) and nitrogen in fumigated and non-fumigated sets was determined by Kjeldahl digestion-distillation-titration method (Black, 1965). The grain yield of rice was recorded after the harvest of crop.

\section{Statistical analyses}

The data was processed as per the procedure of R.B.D (Snedecor and Cochran, 1967), using STPR software of G.B.P.U.A. \& T., Pantnagar. Correlation coefficients were computed using SPSS programme (SPSS, 1990).

\section{Results and Discussion}

\section{Biological indices}

Various biological indices of soil quality were significantly influenced due to the balanced and imbalanced nutrient supply through various levels of chemical fertilizers alone and with FYM in rice under rice-wheat crop rotation in Mollisols for 30 years.

\section{Dehydrogenase activity}

Dehydrogenase activity in surface layer (0-15 $\mathrm{cm}$ ) increased significantly due to application of all fertilizer combinations alone and with FYM for 30 years except $\mathrm{N}_{120}$ and $\mathrm{N}_{120}+\mathrm{K}_{40}$. Application of $\mathrm{N}_{180}+\mathrm{P}_{80}+\mathrm{K}_{40}+\mathrm{Zn}(\mathrm{F})+$ FYM supported highest dehydrogenase activity which was significantly higher than all other treatments. In $15-30 \mathrm{~cm}$ and $30-60$ $\mathrm{cm}$ soil layer too, application of $\mathrm{N}_{180}+\mathrm{P}_{80}+$ $\mathrm{K}_{40}+\mathrm{Zn}(\mathrm{F})+\mathrm{FYM}$ resulted in highest dehydrogenase activity of 174.58 and 125.97 $\mu \mathrm{g}$ TPF $24 \mathrm{~h}^{-1} \mathrm{~g}^{-1}$, respectively (Table 2). The enhanced dehydrogenase activity in soil receiving balanced fertilization along with FYM could be due to improvement in soil organic carbon, total $\mathrm{N}$ and $\mathrm{P}$ status through incorporated FYM, enhanced root biomass, and rhizodeposition that enhanced the microbial proliferation leading to stimulated microbial activity and organic matter degradation vis-a-vis dehydrogenase activity in soil. Organic and integrated nutrient supply (FYM; NP + FYM; NPK + FYM) supported the highest dehydrogenase activity (Srinivas et al., 2015; Bhatt et al., 2016; Liu et al., 2010). The enhanced dehydogenase activity was due to higher organic matter content and relatively higher microbial activity as 
indicated by higher MBC. Dehydrogenase activity is influenced by the quality than by the quantity of organic matter incorporated into soil. Thus, the stronger effects of farm yard manure on dehydrogenase activity might be due to the more easily decomposable components of farm yard manure on the metabolism of soil microorganisms (Pancholy and Rice, 1973).

\section{Urease activity}

Long-term fertilizer application at varying doses with or without FYM significantly influenced the urease activity at all the depths up to $60 \mathrm{~cm}$. The highest amount of $\mathrm{NH}_{4}-\mathrm{N}$ derived through urease activity to the tune of 2.87, 2.17 and $1.14 \mathrm{mg} \mathrm{NH}_{4}-\mathrm{N} \mathrm{g}^{-1}$ soil $\mathrm{h}^{-1}$ due to application of $\mathrm{N}_{180}+\mathrm{P}_{80}+\mathrm{K}_{40}+\mathrm{Zn}(\mathrm{F})+$ FYM for 30 years in $0-15,15-30$ and $30-60$ $\mathrm{cm}$, respectively and lowest in the absence of extraneous supply of nutrients i.e. control (Table 2). The beneficial effects of FYM + NPK on soil urease activity may be attributed to higher level of organic carbon and nitrogen that led to greater microbial proliferation in soil vis-à-vis greater amount of urease enzyme synthesis. The stimulatory effects of nutrient supply through organic sources on urease activity are evident in the literature (Bhatt et al., 2016; Jadhav et al., 2016; Saha et al., 2008).

\section{Microbial respiration}

Microbial respiration or $\mathrm{CO}_{2}$ evolution represents overall metabolic efficiency in soil thus it is considered as an indicator of microbial activity. Microbial respiration activity ranged from 0.89 to $2.90,0.69$ to 1.91 and 0.13 to $1.10 \mu \mathrm{g} \mathrm{CO}_{2}-\mathrm{C} 100 \mathrm{~g}^{-1}$ soil h$^{-1}$ at $0-15, \quad 15-30$, and $30-60 \mathrm{~cm}$ soil layer, respectively. The highest activity was supported by $\mathrm{N}_{180}+\mathrm{P}_{80}+\mathrm{K}_{40}+\mathrm{ZnF}+\mathrm{FYM}$ In all the depths of soil profile up to $60 \mathrm{~cm}$ (Table 3). The increase in microbial respiration activity in soil, due to addition of
FYM along with inorganic fertilizers can be ascribed to enhanced availability of $\mathrm{C}$ from FYM, root biomass and rhizodeposition which act as an energy source for microorganisms native to the soil and FYM. The enhanced microbial respiration indicates the increased microbial activity, leading to enhanced mineralization and consequent release of $\mathrm{CO}_{2}$. Liu, et al., (2010) recorded the highest microbial respiration in soil (6.01 $\mu \mathrm{g} \quad \mathrm{CO}_{2}-\mathrm{C} \mathrm{g}^{-1}$ day $^{-1}$ ) under $\mathrm{NP}+\mathrm{FYM}$ treatment followed by FYM treatment and lowest (3.99 $\mu \mathrm{g} \mathrm{CO}_{2}-\mathrm{C} \mathrm{g}^{-1}$ day $^{-1}$ ) in control. These results also corroborate with the findings of Bhatt et al., (2016), they reported the maximum and significantly higher $\mathrm{CO}_{2}$ evolution with $100 \% \mathrm{NPK}+15 \mathrm{t} \mathrm{FYM} \mathrm{ha}^{-1}$ over all other treatments, after both rice and wheat crops, was evident.

\section{Microbial biomass nitrogen}

The synthesis of microbial biomass nitrogen in surface layer $(0-15 \mathrm{~cm})$ was significantly influenced due to varying doses of fertilizer application alone or in combination with FYM over control except $\mathrm{N}_{120}$ and and $\mathrm{N}_{120}+$ $\mathrm{K}_{40}$. The highest microbial biomass nitrogen synthesis (42.78 $\mu \mathrm{g} \mathrm{g}^{-1}$ ) was supported by application of $\mathrm{N}_{180}+\mathrm{P}_{80}+\mathrm{K}_{40}+\mathrm{Zn}(\mathrm{F})+$ FYM, in 0-15 cm layer. While in 15-30 and $30-60 \mathrm{~cm}$ layer greatest microbial biomass nitrogen was synthesized due to $\mathrm{N}_{120}+\mathrm{P}_{40}+$ $\mathrm{K}_{40}+\mathrm{Zn}(\mathrm{F})+\mathrm{FYM}$ followed by $\mathrm{N}_{180}+\mathrm{P}_{40}+$ $\mathrm{K}_{40}+\mathrm{Zn}(\mathrm{F})+\mathrm{FYM}$ which were at par with each other while lowest MBN was registered in control (Table 3). The lower amount of MBN in control could be attributed to low amount of substrate/food for microbes. High soil organic carbon, more root incorporation and additional supply of organic substrate through FYM for the microorganisms supported the improved microbial biomass nitrogen. Microbial biomass in soil is dynamic and responds to crop input such as fertilization (McGill et al., 1986, Garcia and Rice, 1994). Liu et al., (2010) measured the 
highest microbial biomass nitrogen $(56.2 \mathrm{mg}$ $\mathrm{kg}^{-1}$ ) in soil under $\mathrm{NP}+\mathrm{FYM}$ treatment followed by FYM treatment and lowest (17 $\mathrm{mg} \mathrm{kg}^{-1}$ ) in control.

\section{Grain yield}

Grain yield of rice varied from 2118 to 6825 $\mathrm{kg} \mathrm{ha}{ }^{-1}$ with the application of various fertilizer with or without FYM and effects produced due to different combination of fertilizer application were statistically significant in all the treatments over control. Maximum grain yield was recorded with $\mathrm{N}_{120}$ $+\mathrm{P}_{40}+\mathrm{K}_{40}+\mathrm{Zn}(\mathrm{F})+\mathrm{FYM}$ which was at par with $\mathrm{N}_{120}+\mathrm{P}_{40}+\mathrm{K}_{40}$ and $\mathrm{N}_{180}+\mathrm{P}_{40}+\mathrm{K}_{40}+$ $\mathrm{Zn}(\mathrm{F})+\mathrm{FYM}$ and minimum in control (Table 3). The increase in grain yield of rice due to addition of organics through FYM may be attributed to supply of $\mathrm{N}, \mathrm{P}, \mathrm{K}$ and micronutrients in addition to the recommended dose of fertilizers and increase in total $\mathrm{N}, \mathrm{P}$ and $\mathrm{K}$ uptake. An application of FYM also acts a source of substrate for microbial metabolism resulting in enhanced microbial activity and subsequently nutrient transformations resulting in enhanced plant growth and yield. Thind et al., (2016) reported increase in $\mathrm{N}, \mathrm{P}$ and $\mathrm{K}$ uptake to the tune of 29 to $32 \%, 29$ to $33 \%$ and 27 to $49 \%$ in wheat due to FYM which increased grain and straw yield. The variation in increasing crop yield under the organic inputs might be attributed to the composition of organic materials since carbon and nitrogen mineralization are largely influenced by the quality of plant materials. The integrated supply of nutrients found beneficial in recording higher grain and straw yield of rice.

Relationship between enzymatic activities, microbial respiration, microbial biomass nitrogen and yield

Correlations studies showed a significant relationship $(\mathrm{P}=0.01)$ among soil enzymes, microbial respiration, microbial biomass nitrogen and yield in all the three soil depths (Table 4). Correlation coefficients were found dissimilar between above parameters in three soil depths. This indicates differential microbial activities as well as addition of nutrients under long-term fertilizer and FYM application. In all the three depths the MBN found to be strongly correlated with DHA and UA which indicates that the enzymes are of microbial origin. The strong relationship between MBN and MR depicts the higher metabolism of microbes in the presence of adequate supply of nutrients.

Table.1 Soil properties of experimental soil initially in 1984

\begin{tabular}{|c|c|}
\hline Parameters & Values \\
\hline Textural class & Silty loam \\
\hline $\left.\mathrm{pH}(1: 2.5 \mathrm{soil} \mathrm{water})^{-1}\right)$ & 8.0 \\
\hline EC $\left(\mathrm{dS} \mathrm{m}^{-1}\right)$ & 0.12 \\
\hline Bulk density $\left(\mathrm{g} \mathrm{cm}^{-3}\right)$ & 1.33 \\
\hline CEC (meq $100 \mathrm{~g}^{-1}$ soil) & 20.0 \\
\hline Organic matter $(\%)$ & 2.1 \\
\hline Total nitrogen $(\%)$ & 0.1 \\
\hline Available Phosphorus $\left(\mathrm{kg} \mathrm{P} \mathrm{ha}^{-1}\right)$ & 20.0 \\
\hline Available potassium $\left(\mathrm{kg} \mathrm{K} \mathrm{ha}{ }^{-1}\right)$ & 222.0 \\
\hline Available Zn $(\mathrm{ppm})$ & 0.8 \\
\hline
\end{tabular}


Table.2 Impact of long-term balanced and imbalanced fertilization for 30 years in Rice-Wheat cropping system on dehydrogenase Activity (DHA) and urease activity in $0-60 \mathrm{~cm}$ profile after rice

\begin{tabular}{|c|c|c|c|c|c|c|}
\hline \multirow[t]{2}{*}{ Treatments } & \multicolumn{3}{|c|}{ DHA ( $\mu$ g TPF $24 h^{-1} g^{-1}$ soil) } & \multicolumn{3}{|c|}{ Urease activity $\left(\mathrm{mg} \mathrm{NH}_{4}-\mathrm{N} \mathrm{g}^{-1} \mathrm{~h}^{-1}\right)$} \\
\hline & $0-15 \mathrm{~cm}$ & $15-30 \mathrm{~cm}$ & $30-60 \mathrm{~cm}$ & $0-15 \mathrm{~cm}$ & $15-30 \mathrm{~cm}$ & $30-60 \mathrm{~cm}$ \\
\hline $\mathbf{T}_{1}$ Control & 154.08 & 126.82 & 15.70 & 1.56 & 1.09 & 0.22 \\
\hline $\mathbf{T}_{2} \mathrm{~N}_{120}$ & 166.68 & 133.66 & 24.12 & 1.59 & 1.17 & 0.29 \\
\hline $\mathbf{T}_{\mathbf{3}} \mathrm{N}_{120}+\mathrm{P}_{40}$ & 216.52 & 140.00 & 58.06 & 1.83 & 1.40 & 0.45 \\
\hline $\mathbf{T}_{4} \mathrm{P}_{40}+\mathrm{K}_{40}$ & 201.32 & 136.68 & 52.43 & 1.71 & 1.36 & 0.37 \\
\hline $\mathbf{T}_{\mathbf{5}} \mathrm{N}_{120}+\mathrm{K}_{40}$ & 169.16 & 136.13 & 38.52 & 1.67 & 1.28 & 0.33 \\
\hline $\mathbf{T}_{6} \mathrm{~N}_{120}+\mathrm{P}_{40}+\mathrm{K}_{40}$ & 225.20 & 144.20 & 70.18 & 2.18 & 1.71 & 0.60 \\
\hline $\mathbf{T}_{7} \mathrm{~N}_{120}+\mathrm{P}_{40}+\mathrm{K}_{40}+\mathrm{Zn}(\mathrm{F})$ & 229.71 & 152.73 & 74.90 & 2.33 & 1.78 & 0.84 \\
\hline $\mathbf{T}_{\mathbf{8}} \mathrm{N}_{120}+\mathrm{P}_{40}+\mathrm{K}_{40}+\mathrm{FYM}$ & 247.64 & 164.37 & 100.11 & 2.45 & 2.05 & 1.11 \\
\hline $\mathbf{T}_{\mathbf{9}} \mathrm{N}_{120}+\mathrm{P}_{40}+\mathrm{K}_{40}+\mathrm{Zn}(\mathrm{F})+\mathrm{FYM}$ & 251.48 & 173.74 & 117.50 & 2.64 & 2.09 & 1.12 \\
\hline $\mathbf{T}_{\mathbf{1 0}} \mathrm{N}_{180}+\mathrm{P}_{80}+\mathrm{K}_{40}+\mathrm{Zn}(\mathrm{F})+\mathrm{FYM}$ & 290.37 & 174.58 & 125.97 & 2.87 & 2.17 & 1.14 \\
\hline $\mathbf{T}_{11} \mathrm{~N}_{150}+\mathrm{P}_{80}+\mathrm{K}_{40}$ & 232.28 & 159.14 & 92.97 & 2.37 & 1.82 & 0.87 \\
\hline $\mathbf{T}_{\mathbf{1 2}} \mathrm{N}_{180}+\mathrm{P}_{80}+\mathrm{K}_{40}+\mathrm{Zn}(\mathrm{F})$ & 226.91 & 145.48 & 71.69 & 2.21 & 1.74 & 0.72 \\
\hline $\mathbf{T}_{13} \mathrm{~N}_{180}+\mathrm{P}_{80}+\mathrm{Zn}(\mathrm{F})$ & 237.04 & 160.71 & 96.86 & 2.44 & 1.98 & 1.07 \\
\hline $\mathbf{T}_{14} \mathrm{~N}_{120}+\mathrm{P}_{40}+\mathrm{K}_{40}(\mathrm{DAP})$ & 223.65 & 143.85 & 63.13 & 2.10 & 1.59 & 0.55 \\
\hline S.Em \pm & 12.38 & 6.08 & 3.66 & 0.09 & 0.05 & 0.04 \\
\hline C.D. at 5\% & 36.18 & 17.76 & 10.68 & 0.26 & 0.15 & 0.12 \\
\hline
\end{tabular}

$\mathrm{Zn}(\mathrm{F})$-Foliar Zinc $\left(0.5 \% \mathrm{ZnSO}_{4}+0.25 \%\right.$ Slaked lime); FYM- Farm Yard Manure applied @ $5 \mathrm{t} \mathrm{ha}^{-1}$ on dry weight basis 
Table.3 Impact of long-term balanced and imbalanced fertilization for 30 years in Rice-Wheat cropping system on microbial Respiration, microbial biomass nitrogen $(\mathrm{MBN})$ in $0-60 \mathrm{~cm}$ profile after rice and grain yield of rice

\begin{tabular}{|c|c|c|c|c|c|c|c|}
\hline \multirow[t]{2}{*}{ Treatments } & \multicolumn{3}{|c|}{ Microbial respiration $\left(\mu \mathrm{g} \mathrm{CO}-\mathrm{C} 100 \mathrm{~g}^{-1} \mathrm{~h}^{-1}\right)$} & \multicolumn{3}{|c|}{ MBN ( $\mu \mathrm{g} \mathrm{g}^{-1}$ soil) } & \multirow{2}{*}{$\begin{array}{c}\text { Grain Yield } \\
\left(\mathrm{kg} \mathrm{ha}^{-1}\right)\end{array}$} \\
\hline & $0-15 \mathrm{~cm}$ & $15-30 \mathrm{~cm}$ & $30-60 \mathrm{~cm}$ & $0-15 \mathrm{~cm}$ & $15-30 \mathrm{~cm}$ & $30-60 \mathrm{~cm}$ & \\
\hline $\mathbf{T}_{1}$ Control & 0.89 & 0.69 & 0.13 & 26.51 & 18.57 & 9.81 & 2118 \\
\hline $\mathbf{T}_{2} \mathrm{~N}_{120}$ & 0.92 & 0.71 & 0.20 & 27.76 & 20.82 & 11.10 & 3024 \\
\hline $\mathbf{T}_{\mathbf{3}} \mathrm{N}_{120}+\mathrm{P}_{40}$ & 1.78 & 1.25 & 0.40 & 29.84 & 23.35 & 13.19 & 5102 \\
\hline $\mathbf{T}_{4} \mathrm{P}_{40}+\mathrm{K}_{40}$ & 1.58 & 1.19 & 0.33 & 29.29 & 22.90 & 12.63 & 3080 \\
\hline $\mathbf{T}_{\mathbf{5}} \mathrm{N}_{120}+\mathrm{K}_{40}$ & 1.12 & 0.88 & 0.26 & 28.59 & 21.65 & 11.94 & 2917 \\
\hline $\mathbf{T}_{6} \mathrm{~N}_{120}+\mathrm{P}_{40}+\mathrm{K}_{40}$ & 1.91 & 1.32 & 0.49 & 34.14 & 27.48 & 17.77 & 5399 \\
\hline $\mathbf{T}_{7} \mathrm{~N}_{120}+\mathrm{P}_{40}+\mathrm{K}_{40}+\mathrm{Zn}(\mathrm{F})$ & 2.05 & 1.42 & 0.62 & 35.67 & 28.73 & 19.02 & 5696 \\
\hline $\mathbf{T}_{\mathbf{8}} \mathrm{N}_{120}+\mathrm{P}_{40}+\mathrm{K}_{40}+\mathrm{FYM}$ & 2.57 & 1.45 & 1.02 & 40.25 & 34.31 & 23.60 & 6809 \\
\hline $\mathbf{T}_{\mathbf{9}} \mathrm{N}_{120}+\mathrm{P}_{40}+\mathrm{K}_{40}+\mathrm{Zn}(\mathrm{F})+\mathrm{FYM}$ & 2.71 & 1.58 & 1.08 & 41.22 & 37.84 & 28.12 & 6825 \\
\hline $\mathbf{T}_{10} \mathrm{~N}_{180}+\mathrm{P}_{80}+\mathrm{K}_{40}+\mathrm{Zn}(\mathrm{F})+\mathrm{FYM}$ & 2.90 & 1.91 & 1.10 & 42.78 & 36.28 & 26.57 & 6781 \\
\hline $\mathbf{T}_{11} \mathrm{~N}_{150}+\mathrm{P}_{80}+\mathrm{K}_{40}$ & 2.11 & 1.45 & 0.76 & 36.23 & 29.29 & 19.57 & 6094 \\
\hline $\mathbf{T}_{12} \mathrm{~N}_{180}+\mathrm{P}_{80}+\mathrm{K}_{40}+\mathrm{Zn}(\mathrm{F})$ & 1.98 & 1.39 & 0.53 & 34.42 & 28.20 & 18.49 & 5714 \\
\hline $\mathbf{T}_{13} \mathrm{~N}_{180}+\mathrm{P}_{80}+\mathrm{Zn}(\mathrm{F})$ & 2.44 & 1.44 & 0.86 & 36.39 & 31.45 & 20.74 & 6292 \\
\hline $\mathbf{T}_{\mathbf{1 4}} \mathrm{N}_{120}+\mathrm{P}_{40}+\mathrm{K}_{40}(\mathrm{DAP})$ & 1.85 & 1.28 & 0.46 & 33.31 & 26.37 & 17.66 & 5472 \\
\hline S.Em \pm & 0.04 & $\mathbf{0 . 0 3}$ & $\mathbf{0 . 0 3}$ & $\mathbf{0 . 8 9}$ & 0.86 & 1.10 & 140.51 \\
\hline C.D. at $5 \%$ & 0.12 & 0.09 & 0.07 & 2.61 & 2.52 & 3.22 & 403.44 \\
\hline
\end{tabular}

$\mathrm{Zn}(\mathrm{F})$-Foliar Zinc $\left(0.5 \% \mathrm{ZnSO}_{4}+0.25 \%\right.$ Slaked lime); FYM- Farm Yard Manure applied @ $5 \mathrm{t} \mathrm{ha}^{-1}$ on dry weight basis 
Table.4 Correlations between dehydrogenase activity (DHA), urease activity (UA), microbial respiration $(\mathrm{MR})$, microbial biomass nitrogen $(\mathrm{MBN})$ and grain yield $(\mathrm{GY})$ of rice in

0-60 $\mathrm{cm}$ profile

\begin{tabular}{|c|c|c|c|c|c|c|c|c|c|c|c|c|}
\hline & \multicolumn{4}{|c|}{$0-15 \mathrm{~cm}$} & \multicolumn{4}{|c|}{$15-30 \mathrm{~cm}$} & \multicolumn{4}{|c|}{$30-60 \mathrm{~cm}$} \\
\hline & DHA & UA & MR & MBN & DHA & UA & MR & MBN & DHA & UA & MR & MBN \\
\hline UA & $0.950^{* *}$ & & & & $0.962^{* *}$ & & & & $0.962^{* *}$ & & & \\
\hline MR & $0.975^{* * *}$ & $0.963^{* * *}$ & & & $0.890^{* * *}$ & $0.931^{* * *}$ & & & $0.978^{* * *}$ & $0.983^{* * *}$ & & \\
\hline MBN & $0.939^{* * *}$ & $0.984^{* *}$ & $0.964^{* *}$ & & $0.980^{* * *}$ & $0.981^{\text {*** }}$ & $0.900^{* * *}$ & & $0.966^{* * *}$ & $0.958^{* *}$ & $0.972^{* * *}$ & \\
\hline GY & $0.934^{* * *}$ & $0.936^{* * *}$ & $0.948^{* * *}$ & $0.925^{* * *}$ & $0.895^{* * *}$ & $0.950^{* * *}$ & $0.910^{* * *}$ & $0.921^{* * *}$ & $0.931^{* * *}$ & $0.926^{* * *}$ & $0.907^{* *}$ & $0.915^{*}$ \\
\hline
\end{tabular}

Similarly, GY showed a strong positive relationship with MBN, DHA, UA and MR representing the increase in yield with increase in enzymatic and microbial activities. Significant correlations of GY with MR, MBN and enzyme assessed implies the importance of organic inputs in nutrient cycling as well as improving soil quality (Nayak et al., 2007, Liu et al., 2009). At 0-15 $\mathrm{cm}$ soil layer, significant correlations were observed between DHA and GY $\left(\mathrm{r}=0.934^{* * *}\right)$; $\mathrm{UA}$ and GY $\left(\mathrm{r}=0.0 .936^{* * *}\right) ; \mathrm{MBN}$ and GY $\left(\mathrm{r}=0.925^{* *}\right)$ and; MR and GY $\left(\mathrm{r}=0.948^{* *}\right)$. Similar trend of the relationship between these parameters was noticed at 15-30 and 30$60 \mathrm{Cm}$ depths (Table 4).

The close relationship between enzymatic activities with SOC content might be due to the promoting effects of SOC on MBC, MBN and enzyme activities (Baligar et al., 1999). Sangma, et al., (2016) observed the positive correlations between $\mathrm{MBN}$ and DHA $\left(\mathrm{r}=0.57^{* *}\right), \mathrm{SR}$ and MBN ( $\left.\mathrm{r}=0.38\right)$ and Nath et al., (2012) reported a significant correlations of rice yield with DHA activity $(\mathrm{r}=0.77 * *)$. Significant correlation between the enzymes exhibited the prevalence of intracellular and extracellular enzymes in paddy soil that offer steady biological activity and soil functionality under organic amendments.

After 30 years of experiment in Mollisols of Pantnagar (India), continuous application of balanced inorganic fertilizer alone or in conjunction with farm yard manure has a significant effect on soil respiration, microbial biomass nitrogen and enzymatic activities i.e. dehydrogenase and urease activity; and grain yields of rice. Application of recommended doses of NPK and FYM improved the soil quality parameters which in turn supported better crop productivity. The enhanced rice grain yield due to balanced supply of nutrients through chemical fertilizers and FYM are supported through significant positive correlations between MBN, enzymes, MR and grain yield. Thus, the study concludes the importance of balanced fertilization and addition of FYM to the soil for successful soil quality management. The adoption of these recommendations in the field will ensure the sustainability of rice production through maintenance/ improvement in the biological soil quality. These practices to farmers to minimize the input costs of production and improve agriculture economy.

\section{Acknowledgements}

The authors are grateful to G. B. Pant University of Agriculture and Technology, Pantnagar, India for providing the support to undertake the studies.

\section{References}

Acton, D. F., and Gregorich, L., 1995. The health of our soils: toward sustainable agriculture in Canada. Agriculture Agri- 
Food Canada, CDR Unit, Ottawa, ON.

Anderson, J. P. E., 1982. Soil respiration. In A.L. Page, R.H. Miller and D.R. Keeney (ed.), Methods of Soil Analysis, Part 2. Chemical and Microbiological properties, Agronomy Monograph No.9, Agron. Soc. Am., Soil Sci. Soc. Am., Madison, WI, 831-871.

Baligar, V. C., Wright, R. J., Fageria, N. K. and Pitta, G. V. E., 1999. Enzyme activities in cerrado soils of Brazil. Comm. Soil Sci. Plant Anal., 30: 15511560 .

Belay, A., Claassens, A. S. and Wehner, F. C., 2002. Effect of direct nitrogen and potassium and residual phosphorous fertilizers on soil chemical properties, microbial components and maize yield under long-term crop rotation. Biol. Fertil. Soil, 35: 420-427.

Bhatt, B., Chandra, R., Shri Ram and Pareek, N., 2016. Long-term effects of fertilization and manuring on productivity and soil biological properties under rice (Oryza sativa)wheat (Triticum aestivum) sequence in Mollisols. Archives of Agronomy and Soil Science, 62(8): 1109-1122

Black, C. A., 1965. Methods of soil analysis. Part 2. American Society of Agronomy, inc. Madison, Wisconsin, U. S. A.

Brookes, P. C., Landman, A., Pruden, G. and Jenkinson, D. S., 1985. Chloroform fumigation and the release of soil nitrogen: a rapid direct extraction method for measuring microbial biomass nitrogen in soil. Soil Biol. Biochem., 6: 837-842.

Casida, L. E., Hr., Klein, D. A. and Santoro, T., 1964. Soil dehydrogenase activity. Soil Science, 98: 371-378.

Deng, S.P., and Tabatabai, M.A., 1997. Effect of tillage and residue management on enzyme activities in soils. III Phosphatases and arylsulfatase. Biol. Fertil. Soils, 24: 141-146.
Dick, R.P., Rasmussen, P.E. and Kerle, E.A., 1988. Influence of long-term residue management on soil enzyme activities in relation to soil chemical properties of a wheat-fallow system. Biol. Fertil. Soils, 6: 159-164.

Dick, R.P., Sandor, J.A. and Eash, N.S., 1994. Soil enzyme activities after 1500 years of terrace agriculture in the Colca Valley, Peru. Agric. Ecosyst. Environ, 50: 123-131.

Garcia, F. O., and Rice, C. W., 1994. Microbial biomass dynamics in tallgrass prairie. Soil Sci. Soc. Am. J., 58: 816823.

Jadhav, A. B., Kaldag, A. D. and Amrutsagar, V. M., 2016. Soil Enzymes Activities, Organic Carbon and Microbial Population as Influenced by Integrated Nitrogen Management for Banana. Journal of Indian Society of Soil Science, 64(1): 98-107.

Kirchner, M.J., Wollum, A.G. and King, L.D., 1993. Soil microbial populations and activities in reduced chemical input agroecosystems. Soil Sci. Soc. Am. J., 57: 1289-1295.

Ladha, J. K., Fischer, K. S., Hossain, M., Hobbs, P. R. and Hardy, B., 2000. Improving the productivity and sustainability of rice-wheat systems of the Indo-Gangetic Plains: a synthesis of NARS-IRRI partnership research. IRRI Discussion Paper No. 40, 31.

Liu, E., Yan, C., Mei, X., Bing, H., Ding, L., Liu, Q., Shuang-Liu, S. and Fan, T., 2010. Long-term effect of chemical fertilizer, straw, and manure on soil chemical and biological properties in northwest China. Geoderma, 158: 173180.

Liu, M., Hu, F., Chen, X., Huang, Q., Jiao, J., Zhang, B. and Li, H., 2009.Organic amendments with reduced chemical fertilizer promote soil microbial development and nutrient availability in 
a subtropical paddy field: The influence of quantity, type and application time of organic amendments. Appl. Soil Ecol., 42: 166-175.

Livia, B., Uwe, L. and Frank, B., 2005. Microbial biomass, enzyme activities and microbial community structure in two European long-term field experiments. Agric. Ecosyst. Environ, 109: 141-152.

Masto, R. E., Chhonkar, P. K., Singh, D. and Patra, A. K., 2006. Changes in Soil Biological and Biochemical Characteristics in a Long-Term Field Trial on a Sub-Tropical Inceptisol. Soil Biology and Biochemistry, 38: 15771582.

Mc Gill, W. B., Cannon, K. R., Robertson, J. A. and Cook, F. D., 1986. Dynamics of soil microbial biomass and water soluble organic carbon in Breton after 50 years of cropping to two rotation. Can. J. Soil Sci., 66: 1-19.

Nath, D. J., Baruah, R. Ozah, B., Gogoi, D., Barooah, R. C and Borah, D. K., 2012. Potentiality of diverse organic inputs with low chemical fertilizer on microbial biomass carbon. Soil enzymes and crop yield in paddy soil. Indian $\mathrm{J}$. Agric. Res.., 46 (3): 249-255.

Nayak, D. R., Babu, Y. J. and Adhya, T. K., 2007. Long-term application of compost influences microbial biomass and enzyme activities in a tropical Aeric Endoaquept planted to rice under flooded condition. Soil Biol. Biochem., 39:1897-1906.

Pal, S., and Chhonkar, P. K., 1981. Urease activity in relation to soil characteristics. Pedobiologia, 21: 152158.

Pancholy, S. L., and Rice, E. L., 1973. Soil enzymes in relation to old field succession: amylase, cellulase, invertase, dehydrogenase, and urease. Soil Sci. Soc. Am. J., 37: 47-50.
Roldan, A., Salinas-Garcia, J. R., Alguacil, M. M. and Caravaca, F., 2005. Changes in Soil Enzyme Activity, Fertility, Aggregation and $\mathrm{C}$ Sequestration Mediated by Conservation Tillage Practices and Water Regime in a Maize Field. Applied Soil Ecology, 30: 11-20.

Saha, S., Prakash, V., Kundu, S., Kumar, N. and Mina, B. L., 2008. Soil enzymatic activity as affected by long-term application of farm yard manure and mineral fertilizer under a rainfed soybean-wheat system in N-W Himalaya. Eur. J. Soil Biol., 44: 309315.

Sangma, C. B. K., Thakuria, D. and Biam, D. E. D., 2016. Rice Ecosystems in Hill Agriculture: Effects on Soil Biological Pools of Carbon, Nitrogen and Phosphorous. Journal of Indian Society of Soil Science, 64(5): 391-401.

Schloter, M., Dilly, O. and Munch, J. K., 2003. Indicators for evaluating soil quality. Agric. Ecosyst. Environ, 98: 255-262.

Sinsabaugh, R. L., Antibus, R. K. and Linkins, A. E., 1991. An enzymic approach to the analysis of microbial activity during plant litter decomposition. Agric Ecosyst Environ., 34:43-54

Smith J. L., and Paul E. A., 1990. The significance of soil microbial biomass estimations. -In: Bollag J.M., Stotzky G. (ed.) Soil Biochemistry, Marcel Dekker Inc. NY, USA. Vol. 6, pp 357-396.

Snedecor, G. W., and Cochran, W. G., 1967. Statistical Methods. $5^{\text {th }}$ ed. Oxford and IBH Pub. Co. Eton Press, Calcutta. pp. 209- 219.

SPSS, 1990. SPSS/PC+ + Statistics 16.0 SPSS Inc., Michigan Avenue, Chicago, IL,USA.

Srinivas, D., Lakshmi, M. B. and Bhattacharyya, P., 2015. Carbon Pools and Associated Soil Enzymatic 
Activities as Influenced by Long-term Application of Fertilizers and Manure in Lowland Rice Soil. Journal of the Indian Society of Soil Science, 63(3): 310-319.

Thind, H. S., Sharma, S., Singh, V., Sran, H. S., Singh, B. and Singh, Y., 2016. Integration of Fertilizer Nitrogen, Farmyard Manure and Multi-strain Microorganisms for Sustainable Production of Rice-Wheat System. Journal of Indian Society of Soil Science, 64(1): 78-85
Vance, E. D., Brookes, P. C. and Jenkinson, D., 1987. An extraction method for measuring soil microbial biomass $\mathrm{C}$. Soil Biology and Biochemistry, 19: 703-707.

Wardle, D. A., Yeates, G. W., Nicholson, K. S., Bonner, K. I. and Watson, R. N., 1999. Response of soil microbial biomass dynamics, activity and plant litter decomposition to agricultural intensification over a seven year period. Soil Biol. Biochem., 31, 1707-1720.

\section{How to cite this article:}

Mohd. Yaseen, K.P. Raverkar, Ramesh Chandra, Navneet Pareek, Subhash Chandra and Singh, D.K. 2017. Long-Term Impact of Balanced and Imbalanced Fertilization in Rice under RiceWheat Sequence in Mollisols on Relationship between Microbial Activity and Yield. Int.J.Curr.Microbiol.App.Sci. 6(9): 2107-2117. doi: https://doi.org/10.20546/ijcmas.2017.609.259 